\title{
Removal of heavy metal from casting sand in valve manufacturing industry through bioremediation technique
}

\author{
J. S. Sudarsan ${ }^{1} \cdot$ K. Prasanna ${ }^{1}$ P. Kishorekumar ${ }^{1}$ - S. B. Sanjeev Mohan ${ }^{1}$ • \\ S. Nithiyanantham ${ }^{2,3}$
}

Received: 24 May 2015/Accepted: 31 August 2015/Published online: 15 September 2015

(C) Springer International Publishing 2015

\begin{abstract}
In India, the metal casting industry has been catering to a large market including agriculture and forestry, and the automotive industry for casting of engines, accessories, and international export. Consequently, there are enormous amounts of sand being removed from the casting cycle. To prevent further damage to the environment caused by disposal of this sand, more efficient and environment friendly methods should be adopted. This sand has found reuse in a wide range of applications ranging from agriculture to construction. Use of foundry sand in these fields has proved to be beneficial in waste disposal, in energy saving and so on. Foundry sand is a byproduct from the ferrous and nonferrous metal casting industry. Foundry sand obtained from the latter has been found to contain heavy metals. Most heavy metals are wellknown carcinogenic agents and pose a hazardous impact to life and hence must be treated to permissible limits. Bacterial methods involving the use of bacteria such as Bacillus have proved to be effective in the treatment of
\end{abstract}

S. Nithiyanantham

s_nithu59@rediffmail.com

J. S. Sudarsan

sudarsanjss@yahoo.com

1 Department of Civil Engineering, SRM University, Kattankulathur, Kancheepuram Dt, Kancheepuram, Chennai, Tamilnadu 603203, India

2 School of Physical Sciences and Femtotechnology, SRM University (Applied Energy Resource and Radiation Divisions), Kattankulathur, Kancheepuram Dt, Kancheepuram, Chennai, Tamilnadu 603203, India

3 Post Graduate \& Research Department of Physics, Thiru. A. Govindasamy Arts College (Affiliation with Thiruvalluvar University), Tindivanam, Villupuram Dt, Tamilnadu 604002 , India heavy metals such as aluminum and nickel present by reducing their concentration from as much as $50 \%$ up to $90 \%$.

Keywords Foundry sand - Ferrous and nonferrous . Heavy metals $\cdot$ Carcinogenic agents $\cdot$ Bacillus

\section{Introduction}

Foundry sand is widely used as a molding material due to the easiness of the material involved and due to its unique engineering properties. The primary composition of foundry sand is clean, uniformly sized, high-quality silica sand or lake sand that is bonded to form molds. These sands are used for ferrous metal castings such as iron and steel and also nonferrous metal castings such as copper and aluminum. Ferrous industries account for approximately $95 \%$ of foundry sand used for castings (USDOT, FHWA 2015) The physical and chemical characteristics of foundry sand will depend on the type of casting process and the industry from which it originates. Foundry sands can be classified into two basic types, green sand (referred to as molding sand) and chemically bonded sand. Green sand consists of $85-95 \%$ silica, about $10 \%$ bentonite clay (as the binder), 2-5 \% water and 2-10\% carbonaceous additives, such as seacoal (a carbonaceous mold additive to improve casting finish). The silica sand resists high temperatures and the coating of clay binds the sand together. The water adds plasticity. The carbonaceous additives prevent the "burnon" or fusing of sand onto the casting surface. Green sands also contain trace chemicals such as $\mathrm{MgO}, \mathrm{K} 2 \mathrm{O}$, and $\mathrm{TiO} 2$ (USEPA 2015).

In addition to green sand molds, chemically bonded sand systems are also used. Chemically bonded sand 
consists of 93-99 \% silica and 1-3\% chemical binder. A catalyst initiates the reaction that cures and hardens the mass. There are various chemical binder systems used in the foundry industry. The most common chemical binder systems used are phenolic urethanes, epoxy resins, furfuryl alcohol, and sodium silicates. The type of metal being cast determines which additives and what gradation of sand is used (USEPA 2015). Chemical bonded systems are most often used for cores and molds for nonferrous castings. In this sand casting process, sand is typically recycled and reused through many production cycles. After a number of cycles, this sand becomes unfit for casting purposes and a portion of this sand is replaced with virgin sand. Typically, about one ton of foundry sand is required for each ton of iron or steel casting produced. Environmentally, it is becoming more and more difficult to dispose of great quantities of material into the ground. In addition to the environment reclamation, the process is of value from the conservation point of view. The deposits of high-quality sand will last longer if they are used more efficiently (Patange et al. 2013). The use of foundry sand is being tested in various manufacturing processes as a replacement for virgin sand to improve durability factors in concrete, its use in asphalt concrete and similar utilization (Bakis et al. 2006, Bhimani et al. 2013).

\section{Materials and methods}

Sand casting is the most common technique used around the world. The casting process is efficient in reusing the casting sand over a number of cycles. At a certain point, the sand becomes unfit for the casting process and is disposed. This is known as foundry sand. It exhibits lower unit weight, higher water absorption, and higher percent void compared to regular sand. These properties affect the workability of concrete when used as a replacement Guney et al. 2010, Siddique and Singh 2011). There are more than 5000 foundry units in India, having an installed capacity of approximately 7.5 million tons per annum (IIF 2015). Foundry sands have been used for various landfill and geotechnical applications and also as a replacement for fine aggregate in cement concrete (Abichou et al. 1998, Salokhe and Desai 2014). Discarded foundry sands are contaminated and depending on the industry, they may also contain heavy metals such as aluminum and nickel. Heavy metals are known toxic and carcinogenic agents and present a serious threat to human population and flora and fauna. Biological methods were found to be very effective with the percentage removal above $90 \%$ (Dhokpande and Kaware 2013).

The microbes Pseudomonas aeruginosa, Bacillus and nutrient broth are used in the treatment of heavy metals present in casting sand. They are mixed in varying ratios over varying time periods to identify the microbe having maximum heavy metal biosorption capacity. The basic procedure for the manufacture by sand casting involves melting of the raw metal into which additives are added to obtain the required properties. This molten metal is then poured into the mold which is made of sand. It is left to cool after which the shakeout process is done. After this step, sand is reclaimed for re-use in consecutive molding cycles. Part of the reclaimed sand is removed and treated before being disposed. The flowchart below shows the methodology of the purification process (Fig. 1).

\section{Results and discussions}

The treatment of casting sand containing heavy metals is performed with the microbes Pseudomonas aeruginosa and Bacillus with different ratios and time periods of treatment. Casted sand is treated with Pseudomonas aeruginosa and Bacillus in the ratio 1:0.5 with interval periods of 3 days and 5 days. The results are presented in Fig. 2.

As evident from the above graph, in the 3-day time period and the 5-day period, both bacteria have reduced the concentration of the heavy metals, but both bacteria also have an equal efficiency of treatment. A concentration

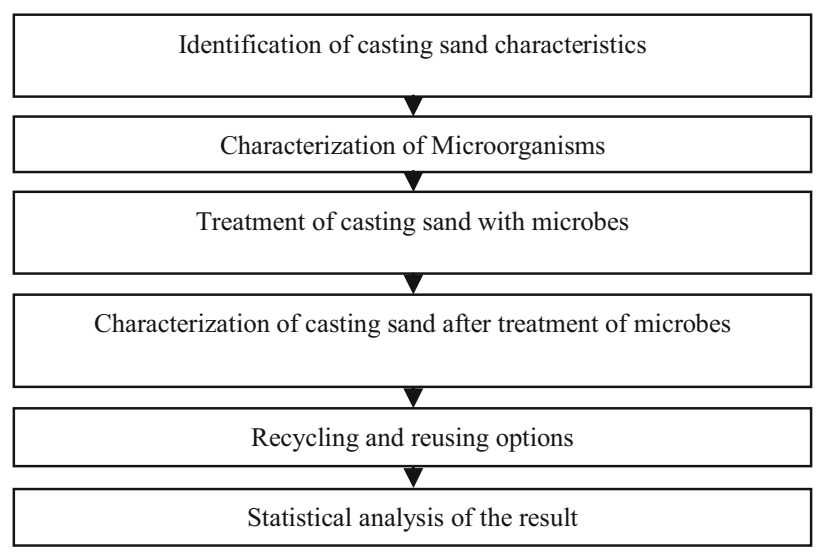

Fig. 1 Methodology of the treatment process

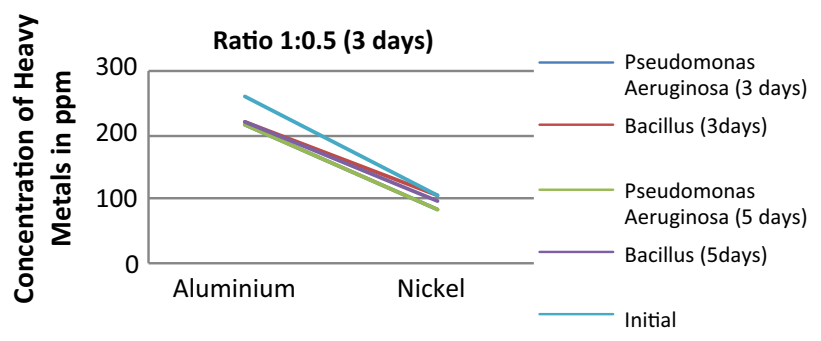

Fig. 2 Composition of heavy metals (ratio 1:0.5-3 days) 


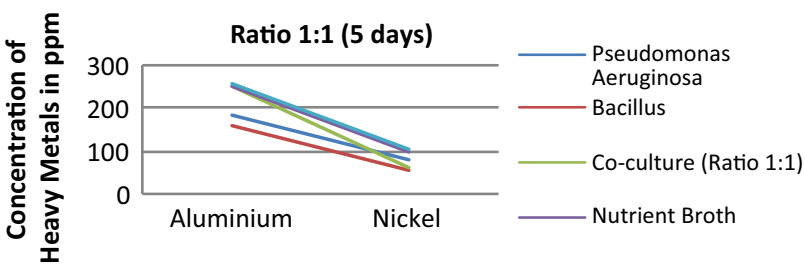

Fig. 3 Composition of heavy metals (ratio $1: 1-5$ days)

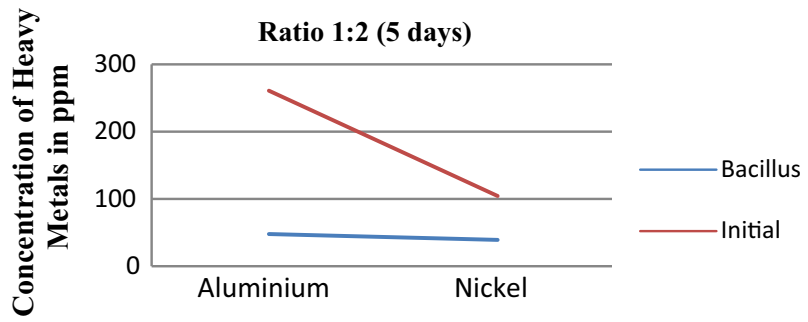

Fig. 4 Composition of heavy metals (ratio 1:2-5 days)

level for aluminum between 217 and $220 \mathrm{ppm}$ and for nickel between 84 and 85 ppm is evident for Bacillus and Pseudomonas aeruginosa. Since there were negligible differences in the composition between the 3-day and 5-day intervals, the sample was further tested by varying the ratio and interval periods.

The sample was then tested with Pseudomonas aeruginosa, Bacillus, a co-culture of Pseudomonas aeruginosa and Bacillus in the ratio 1:1 and nutrient broth without the use of microbes, all in the ratio 1:1 and an interval period of 5 days. The results are depicted in Fig. 3.

It can be inferred from the above graph that in comparison to Pseudomonas aeruginosa, the co-culture of Pseudomonas aeruginosa and Bacillus in the ratio 1:1 and nutrient broth, Bacillus had the most effective results with the aluminum and nickel concentration at 161 and $58.4 \mathrm{ppm}$, respectively, followed by Pseudomonas aeruginosa leaving residual concentrations of aluminum and nickel at 186 and $82 \mathrm{ppm}$, respectively. The co-culture did not degrade any aluminum, but did reduce the nickel concentration to $62.5 \mathrm{ppm}$. The nutrient broth on the other hand did not degrade any heavy metals. From the above results, it was evident that Bacillus is the most efficient in the purification process and thus casting sand was further treated with Bacillus in the ratio 1:2 for an interval of 5 days. The result is depicted in Fig. 4.

As evident from the above graphs if the bacillus ratio is increased, there is a subsequent decrease in the heavy metal concentrations, with aluminum having a concentration of $48 \mathrm{ppm}$ and nickel having a concentration of $40 \mathrm{ppm}$ as compared to the initial concentrations of 258 and $105.85 \mathrm{ppm}$ of aluminum and nickel, respectively. The

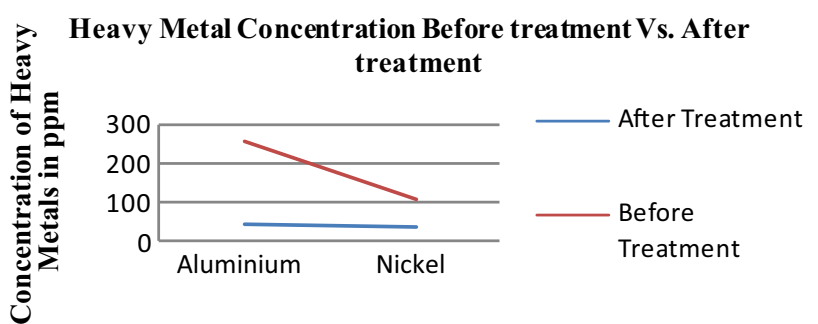

Fig. 5 Heavy metal concentration (before treatment and after treatment)

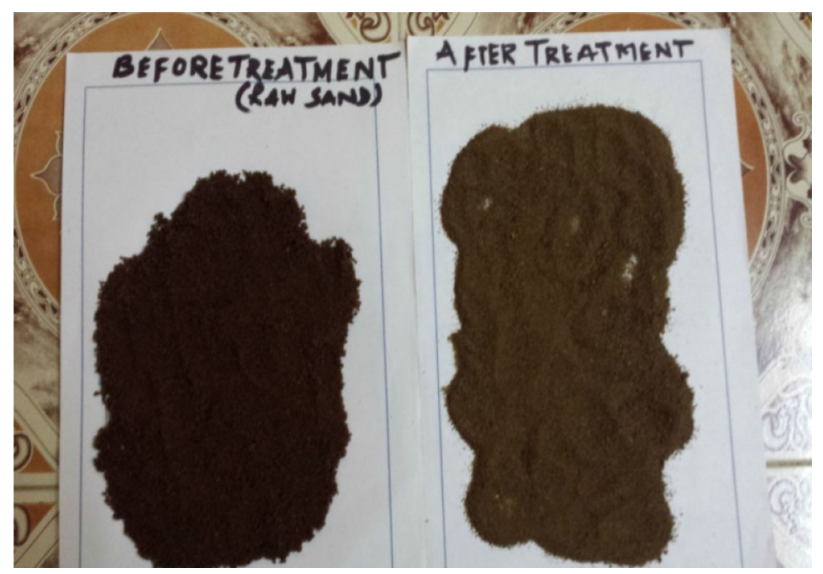

Fig. 6 Casting sand before and after treatment

heavy metal concentration before treatment and after treatment is depicted in Fig. 5.

Considerable change in the physical appearance of the casting sand is seen after the treatment process as depicted in Fig. 6.

\section{Conclusion}

Casting sand contaminated with heavy metals is brought under permissible limits by treating it with the Bacillus microbe. Upon treatment with Bacillus, the heavy metals present in casting sand such as aluminum and nickel have been removed by $60-90 \%$, respectively. Based on the reduction efficiency, it can be concluded that Bacillus can be used as an efficient adsorbent in the treatment of contaminated sand having high aluminum and nickel concentrations. After treatment, this sand can be reused for casting operations. Further study is in progress to use treated casting sand as a replacement for fine aggregate in concrete and thus potentially used for construction, consequently reducing the load on landfills and associated disposal costs. It is a possible source of revenue by converting waste to a valuable by-product or raw material for another process, consequently reducing the demand on sand and quarry resources. 
Acknowledgments The authors are very much grateful for the continuous support of the management of the SRM University, HOD Civil Dept., to complete this work.

\section{References}

Abichou T, Benson C, Edil T (1998) Database on beneficial reuse of foundry byproducts. Recycled materials in geotechnical applications, Geotech. Spec. Publ. No. 79, ASCE, Reston

Bakis R, Koyuncu H, Demirbas A (2006) An investigation of waste foundry sand in asphalt concrete mixtures. Waste Manag Res $24: 269$

Bhimani DR, Pitroda JK, Bhavsar JJ (2013) Effect of used foundry sand and pozzocrete partial replacement with fine aggregate and cement in concrete. Int J Innov Technol explor Eng 2:4

Dhokpande SR, Kaware JP (2013) Biological methods for heavy metal removal. Int J Eng sci Innov Technol (IJESIT) 2(5):304-309

Guney Y, Sari YD, Yalcin M, Tuncan A, Donmez S (2010) Re-usage of waste foundry sand in high strength concrete. Waste Manag 30:1705
Institute of Indian Foundrymen, Commercial Information (2015) http://www.indianfoundry.org/cms-index.php?topsubmenu_id= Ng. Accessed Jan 2015

Patange GS, Khond MP, Rathod HJ, Chhadva KB (2013) Investigation of foundry waste sand reclamation process for small and medium scale indian foundry. Int $\mathbf{J}$ Ind Eng Technol (IJIET) 3(1): 1

Salokhe EP, Desai DB (2014) Application of foundry waste sand In Manufacture of Concrete. IOSR J Mech Civ Eng (IOSR-JMCE) ISSN 22781684:43-48

Siddique R, Singh G (2011) Utilization of waste foundry sand (WFS) in concrete manufacturing. Resour Conserv Recycl 55:885-892

U.S. Department of Transportation, Federal Highway Administration, User Guidelines (2015) http://www.fhwa.dot.gov/publications/ research/infrastructure/structures/97148/fs1.cfm. Accessed Jan 2015

U.S. Environmental Protection Agency, Industrial Materials Recycling Program (2015) Spent foundry sand. http://www.epa.gov/ epawaste/conserve/imr/foundry/. Accessed Jan 2015 